\title{
Bilecik İlinde Tarımsal Üretimin Önündeki Engeller Ve Yapılması Gerekenler Üzerine İçerik Analizi
}

\author{
Mehmet LAÇİN ${ }^{l}$
}

\begin{abstract}
Özet
Bu çalışma Bilecik il merkezi ve ilçelerinde tarımsal üretim yapan üreticilerin tarımsal üretimin önündeki engeller ve üretimin artması için yapılması gerekenler üzerine durmaktadır. Çalışma sonunda elde edilen veriler içerik analizi yöntemiyle incelenmiştir. Bu çalışmaya 135 üretici katılmıştır. Bilecik ilinde tarımsal üretimin önündeki engeller sorgusuyla elde edilen veriler analiz edilmiş ve hiyerarşi grafiğgi oluşturulmuştur. Buna göre tarımsal üretimin önündeki en büyük engel olarak; ilk sırada motorin fiyatlarının yüksek olması $(\% 11,60)$, bunu gübre fiyatlarının yüksek olması $(\% 10,54)$ ve ilaç fiyatlarının yüksek olması $(\% 10,09)$ takip etmektedir. İlk üç sırayı tarımsal girdi kalemlerinin alması dikkat çekmektedir. Tarımsal üretimin artması hususunda üreticilerin görüss ve önerileri tematik formda tablolaştırılmıştır. Elde edilen veriler ışığında 13 kategori elde edilmiştir. . Tarımsal üretimin artması için üreticiler, öncelikle destek ve teşviklerin artmasını, girdi maliyetlerinin düşürülmesini, ihracat ve pazarlamanın artırılmasını, tarımsal kurum ve kuruluşların üreticiye daha fazla destek vermesini talep etmektedirler. Üreticilerin ifadelerindeki kelimelerin tekrar sayısına göre oluşturulan kelime bulutunda; üretim, yüksek, gübre, pazarlama, destekleme, girdi, düşük, yetersiz, pazar, mazot kelimeler öne çıkmaktadır. Sonuç olarak üreticilerin en temel sorunlarının girdi fiyatlarının yüksek, desteklemelerin yetersiz olması ve pazarlama sorunun varlığı ortaya çıkmaktadır.
\end{abstract}

Anahtar Kelimeler: Bilecik, tarım, tarımsal girdi, pazarlama, destekleme

\section{Content Analysis On Barriers To Agricultural Production And Things To Do İn Bilecik}

\begin{abstract}
This study examined the obstacles to production and actions to be taken to increase the production of agricultural producers in Bilecik city center and its provinces. The data obtained from the questionnaire were analyzed by means of content analysis. 135 agricultural producers participated in this study to reflect their opinions and give suggestions related to the production issue. The data obtained from the questionnaire were analyzed and a hierarchy chart was created. Accordingly, the results showed that the biggest obstacle in front of agricultural production was the fuel prices that stand at a high level (11.60\%), followed by high fertilizer prices (10.54\%), and high pesticide prices $(10.09 \%)$. It is noteworthy that agricultural main items took the first three orders. The opinions and suggestions of the producers regarding the increase of agricultural production were tabulated in thematic form. The obtained data were classified into 13 categories. In order to increase agricultural production, producers were firstly asking for increased support and incentives, decreased input costs, increased export and marketing opportunities, more support from the agricultural institutions and organizations. In the word cloud based on the repetition of the words in the words of the producers; production, high, fertilizer, marketing, support, input, low, inadequate, market, fuel words became prominent. As a result, the most basic problems of the producers are high input prices, inadequate support, and marketing problems
\end{abstract}

Keywords: Bilecik, agriculture, agricultural inputs, marketing, support

1 Yüksek lisans mezunu, Bilecik Şeyh Edebali Üniversitesi, Sosyal Bilimler Enstitüsü, İşletme Anabilim Dal1, mlacin42@gmail.com 


\section{Giriş}

Tarım kısaca bitkisel ve hayvansal üretim ile su ürünleri üretimi (Burada su ürünleri üretimin de yazılması uygun olacaktır.) olarak tanımlanabilir. Daha geniş olarak ise bitkisel ve hayvansal üretimin yanında üretilen ürünlerin depolanması, taşınması, işlenmesi ve pazarlanması aşamalarını da içine almaktadır (İnan2006:10). Tarım insanoğlunun varlığıyla birlikte günümüze kadar durmaksızın devam etmektedir. İnsanoğlu önceleri günlük gıda gereksinimini karşılamak için geçimlik tarım yapmaya başlamıştır. Üretimin artmasıyla ihtiyaçtan fazla üretilen ürünlerin diğer insanlarla paylaşılmaya başlamasıyla ticari tarım ortaya çıkmıştır (İnan 2006:11). Tarımsal üretim daha geniş perspektifte tanımlamak gerekirse bitkisel ve hayvansal üretimi teknolojik imkanlar marifetiyle en ekonomik ve verimli olarak gerçekleştirerek, elde edilen ürünlerin hem tüketiciye ulaştırılması veya tarım ürünü işleyen fabrikalara taşınmasıyla ekonomik değer elde edilmesi şeklinde ifade edilebilir (Karacan 2014:3). Tarımsal üretimin birincil işlevi insanoğlunun besin ihtiyacını karşılamaktır. Bu karşılandıktan sonra diğer işlevleri olan tarım dışı sektörlere hammadde temin etme, sağlıklı işgücü sağlama, ruhsal denge unsuru olma, kalkınmanın finansmanını sağlama gibi işlevleri vardır (Dinler 1993: 33). Tarımsal üretim doğal koşullara bağımlı olması nedeniyle birçok risk ve belirsizlikler mevcuttur (İnan 2006: 14). Diğer sektörlerde olmayan bu kontrol edilemeyen riskler nedeniyle tarım sektörü desteklemeye ihtiyaç duymaktadır. Devlet, tarım sektörüne toplumun gıda ihtiyacını karşılaması, tarım ürünleri fiyatlarının istikrarlı bir seyir izlemesini sağlamak, tarımsal gelir düzeyinin artırılarak yaşam standartlarını yükseltmek, verimliliği ve ürün çeşitliliğini artırmak gayeleriyle çeşitli destekler sağlar(Doğan Burtan 2014:57).Ülkemiz ekonomisi için önemli bir sektör olan tarım sektörü hem istihdam hem de gelir bakımından ağırlı̆̆ını hissettirmektedir. TÜIK'in istihdam edilenlerin yıllara göre iktisadi faaliyet kolları ve dağılımı verilerine göre ülkemizde 2016 y1lı toplam istihdam 27 milyon 205 bindir. 2016 y1lında toplam istihdamda tarımın payı ( \% 19,5) 5 milyon 305 bindir. 2006 yılında bu rakam 4 milyon 653 bin idi. Oransal olarak tarım istidamı sanayi ile aynı seviyededir. İstihdamda \%53,7 ile hizmet sektörü başı çekmektedir. İstihdam açısından tarımın yerini belirttikten sonra Gayri Safi Milli Hasıla'daki (GSMH) yerini de belirtmemiz gerekmektedir. TÜIK'in bitkisel ve hayvansal üretim değerleri verilerine göre 2016 yılında bitkisel ve hayvansal üretim değeri toplamı 269 milyar 671 milyon 586 bin 991 TL'dir( TÜIK,2017). Bu rakamın GSMH'deki payı ise \% 11,73’tür (TÜİK,2018). Bu rakamlar tarım sektörünün ülke ekonomisi bakımından ehemmiyetini açıkça göstermektedir. Bu bağlamda ülke ekonomisinde önemli yere sahip tarım sektörünün Bilecik özelinde içerisinde bulunduğu mevcut durum da önem arz etmektedir. Bu çalışmada Bilecik’teki tarımsal üretimi etkileyen unsurlar sorgulanmıştır. 


\section{1. Çalışmanın Amacı}

Gıda Tarım ve Hayvancılık Bakanlığı, Bitkisel Üretim Genel Müdürlüğü, Türkiye İhracatçılar Meclisi, Devlet Planlama Teşkilatı, Türkiye Ziraat Odaları Birliği, TÜİK, Türkiye Odalar ve Borsalar Birliği, Türkiye Odalar ve Borsalar Birliği gibi ilgili kurum ve kuruluşlar tarafindan anket ve diğer veri elde etme kaynakları kullanılarak tarımsal faaliyetler hakkında bilgiler toplanmakta ve depolanmaktadır. Elde edilen bilgiler ilgiller tarafindan analiz edilmekte, yorumlanmakta ve belli aralıklarla rapor şeklinde kamuoyunun bilgisine sunulmaktadır. Bilecik İl Gıda Tarım ve Hayvancılık Müdürlüğü’nün 2016 Yllı Ill Brifingi, Bitkisel üretim Genel Müdürlügü̈nün 2017 Yllı Bitkisel Üretim Verileri, Türkiye İhracatçılar Meclisi'nin 2016 Yılı Tarım Raporu, Devlet Planlama Teşkilatı'nın Tarım ve Gıda Ürünleri Fiyatlarında Yaşanan Sorunlar ve Önerileri, Türkiye Odalar ve Borsalar Birliği'nin 2013 Yllı Türkiye Tarım Sektörü Raporu, TÜiK'in 2017 Yılı Bitkisel ve Hayvansal Üretim Değerleri, Türkiye Odalar ve Borsalar Birliği’nin 2013 Yılı Türkiye Tarım Sektörü Raporu bunlara birkaç örnek olarak verilebilir. $\mathrm{Bu}$ raporlardan çıkan sonuçlara göre muhataplar stratejilerini belirlemektedir. Bunlar, en iyiye ulaşmak için olması gereken ve yapılması elzem olan çalışmalardır. Ancak bu raporlar, rakamlara ve oranlara dayalı formal çalışmalardır. Ayrıca yoğun istatistiki bilgi sisi içerisinde önemli detaylar gözden kaçmaktadır. En önemlisi üretimin ana unsuru olan üreticinin yaşanmışlığını yansıtmamaktadır. Konu hakkında kaynak taraması sonucunda bizatihi üreticilerden elde edilen bilgiler çerçevesinde Bilecik tarımının sorunlarını ele alan akademik çalışma veya kongre, konferans gibi bir organizasyon tespit edilememiştir. Yukarıda da izah edildiği gibi tarımsal faaliyetlerle alakalı anılan kurum ve kuruluşlar tarafından sayısal veriler yayınlanmaktadır. Ancak sektör içerisinde aktif faaliyet gösterenlerin üretim sırasında karşılaştı̆̆ı sorunlar, sıkıntılar ve üreticilerin çözüm önerilerini vesikalaştıran bir çalışmaya rastlanılmamıştır. İşte bu çalışmanın amacı bu eksikliği gidermek ve gerçeklere ayna tutmaktır. Üreticinin düşüncelerini, karşılaştı̆g 1 sorunlarını ve üretici penceresinden çözüm yollarını ortaya koyabilmek, üreticilerin görüş ve önerilerini tarihe not düşmek ve akademik tartışma zemini oluşturabilmek amacıyla bu çalışma yapılmıştır.

\section{Kapsam, Materyal Ve Yöntem}

Bilecik il merkezinde ve ilçelerinde tarımsal üretim yapan üreticiler çalışma kapsamındadır. $\mathrm{Bu}$ çerçevede Bilecik merkezde ve ağırlıklı olarak Pazaryeri, Yenipazar, Söğüt, Osmaneli ve İnhisar ilçelerinde faaliyet gösteren 135 üretici ile 2016 yılında yüz yüze ve/veya telefonla mülakat ve anket çalışması yapılmıştır. Gıda, Tarım ve Hayvancılık Bakanlığı Bilecik il Müdürlüğü 2014 Çiftçi Kayıt Sistemi (ÇKS) kayıtlarına göre Bilecik’te 7.620 tarımsal ürün üreten üretici olduğu görülmüştür. N sayısı yani Bilecik ilinde faaliyet gösteren üretici sayısı (7.620) belli olduğu için ve çalışmanın amacı, koşulları göz önünde bulundurularak araştırmada oransal örnek hacmi formülü uygulanmış olup, 
örnek hacminin belirlenmesinde hata payı $\% 10$ ve güven aralığı $\% 95$ kabul edilerek anket çalışması yapılacak minimum işletme sayısı hesaplanmıştır. Buna göre (Newbold, 1995:243-276);

$$
n=\frac{W p(1-p)}{(N-1) \sigma^{2} p x+p(1-p)}(1)
$$

Formül 1 ile hesaplama yapılmıştır. Formülde; n: örnek hacmini, N: ana kitleyi=7.620, p: ana kitle oranını $=0,5, \sigma^{2} p x=$ ana kitle oranının varyansını $=0,0026 \quad$ ( \% 95 güven aralığı için $\mathrm{Z}$ dağılım tablo değeri 1,96 ve hata payı 0,10 alınarak) hesaplanmıştır. Yapılan hesaplama sonucunda minimum kaç üretici ile anket çalışması yapılması gerektiği ortaya çıkmıştır. Anket yapılacak minimum üretici sayısının mümkün oldukça çok miktarda çıkması için p değeri 0,5 olarak alınmıştır.

$$
n=\frac{7620 \cdot 0,5 \cdot(1-0,5)}{((7620-1) * 0.0026)+(0.5 *(1-0.5))}=94,96=95
$$

Yukarıda yapılan hesaplama sonucunda en az 95 üretici ile anket yapılması gerektiği sonucu çıkmasına rağmen anket çalışması, Bilecik il merkezinde ve ilçelerinde bulunan 135 üretici ile gerçekleştirilmiştir.

\subsection{Araştırma Verilerinin Çözümlenmesi}

Katılımcılara "tarımsal üretimin önündeki en büyük engel hangisi/hangileri” sorusu yöneltilmiştir. Cevaplarda 14 seçenek sunulmuştur. Konuyla alakalı bir çok etkenin olması nedeniyle katılımcıların birden fazla seçeneği işaretlemesine izin verilmiş ve sonuçları grafik haline getirilmiştir ( Grafik 1). Diğer taraftan açık uçlu "tarımsal üretimin artması için sizce öncelikle neler yapılmalıdır" sorusu katılımcılara yöneltilmiş, alınan yanıtlar Tablo 2 'de çizelge halinde gösterilmiştir. Elde edilen bilgilere sosyal bilimler için nitel veri analizi olan içerik analizi uygulanmıştır. İçerik analizi, çok çeşitli ifadelere uygulanan bir takım metodolojik araç ve tekniklerin bütünü şeklinde tanımlanabilir. $\mathrm{Bu}$ araç ve teknikler tümdengelim yöntemi okuma aracı ve yorumlama çabası olarak ifade edilebilir. Anılan okuma, hudutları belirlenmiş söylem örneklerinin çözümlenmesidir (Bilgin2006:1). İçerik analizinin uygulaması dört aşamada gerçekleştirilmiştir. Amaçtan sapmamak ve zaman kaybetmemek için verilerin her yönüyle incelenmesi yerine belirlenen hedef ve amaçlar çerçevesinde analiz edilmesi gerekmektedir. Bu nedenle öncelikle araştırma amacı ve hedefi belirlenmiştir. İkinci olarak örneklem oluşturulmuştur. Üçüncü olarak örneklemler bölünerek kayıt birimleri ve bunların içinde kategoriler oluşturulmuştur. Dördüncü olarak değerlendirme, çıkarsama ve yorumlama yapılmıştır (Bilgin 2006:11).

\section{Araştırmaya İliş̧kin Bulgular}

Bilecik ilinde tarımsal üretim yapan 135 üreticiye yöneltilen biri açık uçlu iki soruya verilen cevaplar çerçevesinde elde edilen bulgular tablo ve resim bulutu haline getirilerek yorumlanmıştır. Ayrıca alan çalışması esnasında yapılan gözlemler ifade edilmiş, üreticilerin ifade ettiği sorunlara öneriler dile getirilmiştir. 


\subsection{Bilecik İlinde Tarımsal Üretimin Önündeki Engeller Ve Tarımsal Üretimin Artması}

\section{İçin Yapılması Gerekenler Üzerine Sosyal Geçerlilik Analizi}

\subsubsection{Bilecik İlindeki Tarımsal Üretimin Önündeki Engeller Bulguları}

Katılımcılara tarımsal üretimin önündeki engeller sorulmuş, 14 madde cevap olarak sunulmuş ve katılımcıların birden fazla seçenek belirlemesine müsaade edilmiştir. Her bir seçeneğin belirtilme sayısına göre oransal sıralama yapılmıştır (Grafik 1). Buna göre tarımsal üretimin önündeki en büyük engel olarak; ilk sırada motorin fiyatlarının yüksek olması (\% 11,60), bunu gübre fiyatlarının yüksek olması (\% 10,54), üçüncü sırada ise ilaç fiyatlarının yüksek olması (\% 10,09) takip etmektedir ( Grafik 1). Bu üç madde tarımsal üretimin ana girdi kalemleridir.

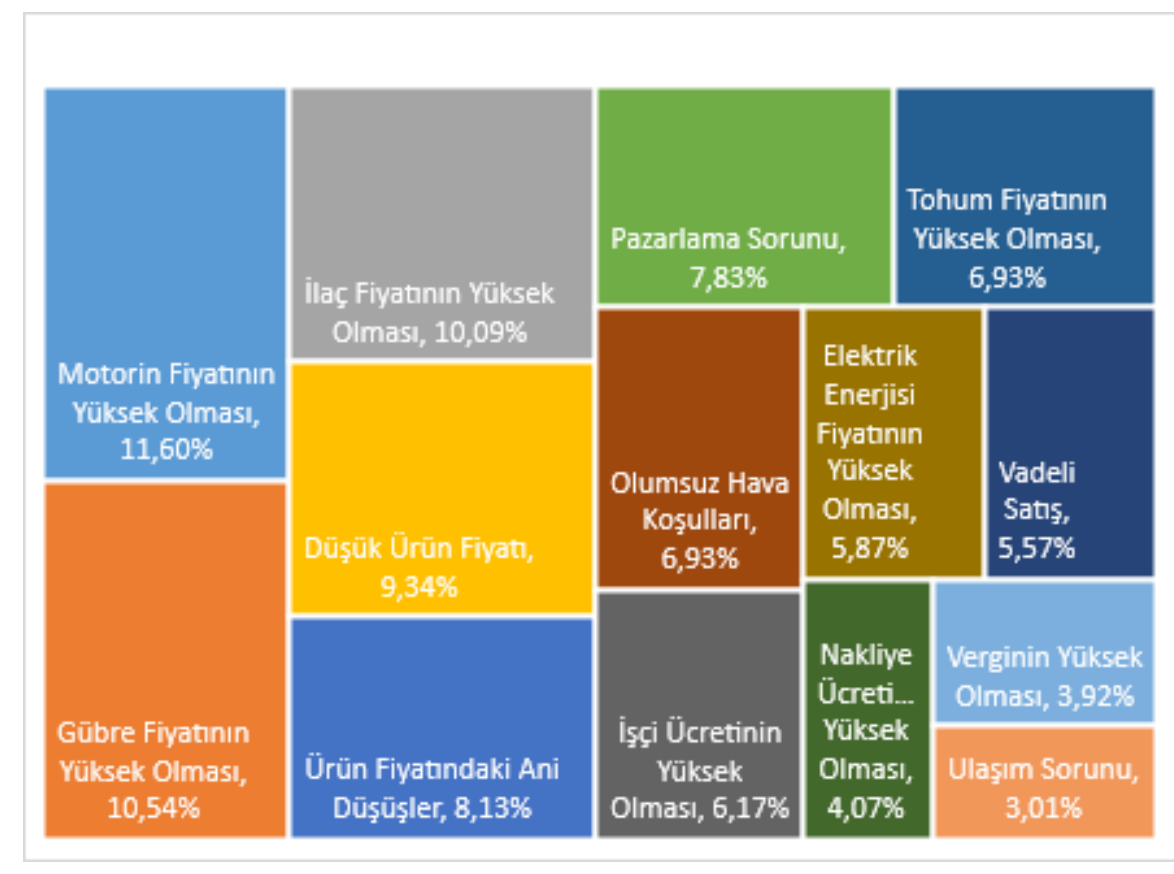

Grafik 1: Bilecik İlindeki Tarımsal Üretimin Önündeki Engeller

İlk üç sıralamanın üretimle ilgili olmasına karşın ikinci üç sıralamada satışla alakalı engeller gelmektedir. Buna göre fiyat ve pazarlama ikinci planda kalmaktadır. Tohum fiyatlarının yüksek olması $(\% 6,93)$ ile olumsuz hava koşulları başa baş gitmektedir (Grafik 1). Üretim için enerji gideri olarak motorin ilk sırada yer alırken, elektrik fiyatının yüksek olmasının $(\% 5,87) 10$. sırada yer alması elektriğin Bilecik’teki tarımsal üretimde motorine göre daha az kullanıldığını göstermektedir. Buradan yola çıkarak tarımsal üretim için motorinin çok önemli olduğu söylenebilir. İşçi ücretlerinin yüksek olması oranın $(\% 6,17)$ 9. sırada yer alması ilde tarım işçisi sayısının ve işçi günlük ücretinin makul olduğu şeklinde değerlendirilebilir. Burada şunu ifade etmek gerekmektedir. Çalışma esnasında üreticilerin genelde aile bireylerinden işgücü tercih ettiği, diğer durumlarda doğu illerinden gelen veya 
mültecilerden düşük ücretlerle işgücü ihtiyacını karşıladıkları gözlemlenmiştir. Bu nedenden dolayı bu maddenin Grafik 1'de son sıralarda yer aldığ 1 düşünülmektedir. Verginin yüksek olması seçeneğinin $(\% 3,92)$ 13. sirada yer alması devletin tarımsal vergileme sisteminde kabul edilebilir bir seviyede olduğunu göstermektedir. Nakliye ücretinin yüksek olması $(\% 4,07)$ sondan üçüncü sırada yer almas1 bölgede lojistik imkanların yeterli olduğunu göstermektedir. Ulaşım sorununun tabloda en son sırada kendine yer bulması bölgede ulaşım ağının yaygın olduğunun belirtisidir. Zira Bilecik'in başta Bursa, Eskişehir, Sakarya gibi büyük illerle komşu olması ve Kocaeli ve İstanbul gibi önemli büyük şehirlere yakın olması ulaşım açsından ili oldukça avantajlı duruma getirmektedir.

2002 y1lında Bilecik'te ocak ayında litresi 0,94 TL (TZOB, 2013) olan motorin \% 442,55 artışla 2017 yılı aralık ayında 5,10 TL'ye yükselmiştir (OPET, 2017). Aradan geçen 15 yılda akaryakıt fiyatlarının astronomik artışı tarımsal üretimi zora sokmaktadır. Önemli girdi kalemindeki bu artış oranı, Grafik 1'de tarımsal üretimin önündeki en büyük engellerin başında motorin fiyatlarının yüksek olması $(\% 11,60)$ sonucunu desteklemektedir. Bir başka tarımsal üretim girdisi olan ve üreticinin yaygın olarak kullandığı Diamonyum Fosfat (DAP) gübre fiyatları incelendiğinde 2003 yılında tonu 388 TL iken 2017 yılında \% 285,02 artışla 1.493,90 TL’ye yükselmiştir (BÜGM 2017:23). Bu sonuç da Grafik 1'de ikinci sırada yer alan gübre fiyatlarının yüksek olması $(\% 10,54)$ sorununu teyit etmektedir. Diğer sektörlerde olduğu gibi tarım sektöründe de temel amaç kar elde etmektir. Üreticileri penceresinden bakıldığında, faaliyetin ve mevcudiyetin sürdürebilmesi kar elde etmekle mümkündür. Aksi durumda yani bunun tersi zarar ortaya çıkması sonucu üreticiler üretimden soğurlar ve üretmeyi bırakırlar. Bu nedenle üretim miktarları düşer. Üretim miktarlarının düşmesi fiyatların yükselmesine neden olur. Akabinde ise sektörde tekelleşme meydana gelebilir. Bilecik'te en yaygın yetiştirilen sebze olan domates örneğinden yola çıkıldığında üreticilerin kar maksimazyonuna ne kadar uzak oldukları daha net anlaşılacaktır. TÜIK'in 2015 yılı tarım ürünleri üretici fiyat endeksi ürün fiyatları raporuna göre 2014 yılı ocak ayında domatesin kilogram satış fiyatı 1,53 TL iken 2015 yılı eylül ayında bu rakam \%35,29 düşüşle 0,99 TL'ye gerilemiştir. Ancak bu düşüş statik değil dalgalı bir şekilde gerçekleşmiştir. 2014 yılı eylül ayında 0,94 düşerken, 2015 yılı nisan ayında 2,08 TL olarak dalgalı seyir izlemiştir. Bu sonuçlar Grafik 1'deki düşük ürün fiyatı $(\% 9,34)$ ve ürün fiyatındaki ani düşüşler $(\% 8,13)$ sorunsallarıyla paralellik arz etmektedir.

\subsubsection{Tarımsal Üretimin Artması İçin Yapılması Gerekenler Üzerine Sosyal Bilimlerde}

\section{İçerik Analizi}

2016 yılında Bilecik il merkezinde ve ilçelerinde tarımsal üretim yapan üreticilerle yapılan çalışmada "tarımsal üretimin artması için sizce öncelikle neler yapılmalıdır" sorusuna katılımcıların verdikleri cevaplar Tablo 1'de sadeleştirilmiştir. 135 katılımcıdan 19'u (\%14,07) soruya cevap vermemiştir. 
Tablo 1: Bilecik illinde Tarımsal Üretimin Artması Için Yapılması Gerekenler

\begin{tabular}{|c|c|}
\hline $\begin{array}{l}\text { KATEGORi } \\
\text { BAŞLIKLARI }\end{array}$ & KATILIMCI NO VE ÖRNEK IFADE \\
\hline $\begin{array}{l}\text { Destekleme } \\
\text { ve Teşvikler }\end{array}$ & $\begin{array}{l}\text { K47: Desteklemeler artmalı } \\
\text { K54: Devlet desteği yetersiz } \\
\text { K60: Teşvikler artırılmalı } \\
\text { K94: Hayvancılık ve tarımda desteklemeler yetersiz } \\
\text { K101: Çiftçiye ürün desteği şart. Kooperatif olarak destekleme şart }\end{array}$ \\
\hline $\begin{array}{l}\text { Üretim } \\
\text { Girdileri }\end{array}$ & $\begin{array}{l}\text { K10: Tarımda kullanılan ilaç gübre mazot giderlerinin düşürülmesi } \\
\text { K15:Girdi maliyetleri çok yüksek } \\
\text { K41:Girdi maliyetlerinin düşürülmesi lazım } \\
\text { K82:Girdi fiyatları çok yüksek } \\
\text { K85:Girdi maliyetleri çok yüksek } \\
\text { K106:Girdi fiyatlarının düşürülmesi }\end{array}$ \\
\hline $\begin{array}{l}\text { İhracat ve } \\
\text { Pazarlama }\end{array}$ & $\begin{array}{l}\text { K5: Ihracat artırılmalı } \\
\text { K34:Pazarlama sorunu giderilmeli } \\
\text { K45:Pazar sorunu çözülmeli yeni pazarlar bulunmalı. Ihracatın önü } \\
\text { açılmalı } \\
\text { K53:Pazarlama sorunu var. Ihracat artırımı yapılmalı } \\
\text { K64: En büyük sıkıntı pazarlama sorunu. Ihracatın artırılması gerekir } \\
\text { K115:Pazarlama sorunu çözülmelidir }\end{array}$ \\
\hline $\begin{array}{l}\text { Tarımsal } \\
\text { Kurum } \\
\text { Kuruluş ve } \\
\text { Odalardan } \\
\text { Destek Alma }\end{array}$ & $\begin{array}{l}\text { K6:Ziraat odası hiçbir iş yapmıyorlar. } 170 \text { TL kayıt ücreti alıyorlar ama } \\
\text { karşılığı verilmiyor } \\
\text { K9:Tarım il Müd. Ziraat Müh. ve veterinerlerde araziye çıkmalı. } \\
\text { Yazışmalardan başını kaldıramıyor } \\
\text { K27:Ziraat personellerinin (Tarım ilı Müdürlüğü) bizimle ilgilenmiyor. } \\
\text { Teknik danışmanlık eksiği } \\
\text { K69:Çiftçi odaları hiç bir iş yapmıyor, gereksiz. Kapatılsın. Bizim } \\
\text { sözümüz dinlenmiyor } \\
\text { K72:Odalarla ilgili düzenleme lazım, boş yere para alıyorlar } \\
\text { K87:Odalar konusunda çalışma yapılmalı, tarım müdürlükleri çalışmıyor }\end{array}$ \\
\hline Eğitim & $\begin{array}{l}\text { K38:Öncelikle çiftçi eğitilmeli } \\
\text { K40:Tüm arıcıların bu konuda bilgisi olan akademisyenler tarafından } \\
\text { eğitilmeli } \\
\text { K90:Hayvansal üretim yapan işletmelerdeki elemanların } \\
\text { bilinçlendirilmesi eğitilmesi şart }\end{array}$ \\
\hline Genç Nüfus & $\begin{array}{l}\text { K88:Genç nüfusun tarım ve hayvancılığa özendirilmesi } \\
\text { K103:Köylerde genç nüfus kalmadı }\end{array}$ \\
\hline Diğer & $\begin{array}{l}\text { K12:Tarımsal üretim aileden işletmelere geçmeli } \\
\text { K98:Hayvansal hastalıklarla mücadele edemiyoruz }\end{array}$ \\
\hline $\begin{array}{l}\text { İşçilik } \\
\text { Ücretleri }\end{array}$ & K75:Iş̧̧̧ilik maliyetleri yüksek \\
\hline Miras Yasası & K79:Miras yasası toprakları bölmemeli \\
\hline
\end{tabular}




\begin{tabular}{|c|l|}
\hline $\begin{array}{c}\text { Üretim } \\
\text { Miktarı Planı }\end{array}$ & K31:Dengesiz tarım üretimi yapılıyor. Üretim miktarları dengelenmeli \\
\hline $\begin{array}{c}\text { istikrarlı } \\
\text { Tarım } \\
\text { Politikası }\end{array}$ & $\begin{array}{l}\text { K28: İstikrarlı ve kararlı tarım politikaları izlenmeli, popülist politikalar } \\
\text { terk edilmeli }\end{array}$ \\
\hline Ulaşım & $\begin{array}{l}\text { K84:Olumsuz hava şartları yollar kapanıyor ulaşım kesiliyor. Merkeze } \\
\text { K111:Ulaşım sorunun giderilmesi }\end{array}$ \\
\hline Vergi & K52: Vergiler yüksek \\
\hline
\end{tabular}

Elde edilen veriler çerçevesinde içerik analizi yapmak üzere 12 kategori belirlenmiş bunların dışında olanlar ise diğer kategorisi içerisine dahil edilmiştir (Tablo 1). Katılımcılar ile yapılan anket çalışmasında yer alan açık uçlu soruya verilen cevaplara sosyal bilimlerde içerik analiz uygulanmıştır. Katılımcıların ne dediğinin en iyi anlaşıldığı teknik olması nedeniyle içerik analizi açık uçlu anket sorularında yer alan açık uçlu sorulara verilen cevapları incelemede sıklıkla kullanılır (Bilgin 2006:58). Bu çalışmada Bilecik ilindeki tarımsal üretimin artması için üreticiler cephesinde yapılması gerekenlerin gerçekçi olarak tespit edilebilmesi için içerik analiz tekniği kullanımı tercih edilmiştir. Katılımcılardan seçilen temsilcilerin örnek ifadeleri Tablo 1'de yer almaktadır. Buna göre ; Tablo'1 incelendiğinde tarımsal destekleme ve teşviklerin yetersiz olduğu çeşitli ifadelerle üreticiler tarafından dile getirildiği görülecektir. 5488 sayılı Tarım Kanunu'nun 21 maddesinde bütçeden tarımsal destekleme için ayrılacak mali kaynağın, GSMH'nın yüzde birinden az olamaz hükmü olmasına rağmen tarımsal destekleme bu seviyeye henüz ulaşılmış değildir. Türkiye'nin 2015 yılı vergi ve süspansiyondan arındırılmış GSMH's1 2 trilyon 60 milyar 726 milyon 789 bin TL'dir (TÜİK 2018). Aynı yıl altı ana başlıkta tarımsal desteklere ayrılan pay ise 9 milyar 971 milyon $(\% 0,48)$ TL'dir (İSKGM,2017). 2016 y1lında bütçeden tarımsal destekleme için 11,60 milyar TL ayrılırken, 2017 yılında bu rakam \% 10,3 artırılarak 12,8 milyar TL seviyesine çıkmıştır. 2017 yılı tarımsal destek kaynak dağılımı; 3,8 milyar TL hayvancılık, 2,2 milyar TL yağlı tohumlu bitkiler, 1,5 milyar TL kırsal kalkınma, 892 milyon TL hububat, 877 milyon TL gübre, 723 milyon TL mazot, 835 milyon TL fındık, 900 milyon TL tarım sigortası, 165 milyon TL çay, 910 milyon TL diğer tarımsal destekler şeklinde gerçekleşmiştir (BÜMKO 2019). 2017 yılı bütçe toplamı 1.243,4 milyar TL'dir. GSMH 2017 yılında 3 trilyon 104 milyar 907 milyon TL olarak gerçekleşmiştir (TÜIK 2018). Bütçeden, tarımsal desteklere ayrılan pay ( 12,8 milyar TL), GSMH'nın yüzde birinden az olarak sadece \% 0,41 seviyesinde kalmıştır. Bu veriler ışığında tarımsal üretim yapan üreticilerin daha fazla desteklenmesi gerektiği söylenebilir. Başka bir kategori olan üretim girdilerini geldiğimizde üreticilerin tarımsal üretim için gerekli olan girdi fiyatlarının yüksek olmasından şikayetçi olduğu görülmektedir. Girdi maliyetinin artması ürün fiyatına yansıması karlılığı da olumsuz etkilemektedir. Modern tarımın gelişimiyle enerji, kimyasal gübre ve hazır yem kullanımı artmıştır. Bu beraberinde maliyet külfeti getirmiştir. 2014 yılında 5,7 milyar dolar tarımsal girdi ithal ederken buna karşın 3 milyar dolar ihracat gerçekleşmiştir (TIMM 2016:121). Ülkemizde ithalata dayalı bir tarımsal girdi söz konusudur. İthalata 
dayalı girdi kullanımı döviz baskısını beraberinde getirmektedir. Bir önceki bölümde motorin ve gübre fiyatlarındaki yüksek artışlardan bahsetmiştik. Tüm bu bilgiler çalışmaya katılan üreticilerin tarımsal girdi maliyetlerinin yüksek olması nedeniyle üretimde zorlandıklarını göstermektedir. Tarımsal üretim ve verimliliğin artması için girdi maliyetlerinin düşürülmesi zorunluluk olarak karşımızda durmaktadır. Tablo 1'de ihracat ve pazarlama kategorisine baktığımızda pazarlama sorunun bariz varlığı göze çarpmaktadır. Bu durumu üretim değeri verileri de desteklemektedir. TÜİK'in bitkisel ve hayvansal üretim değerleri verilerine göre Türkiye'de 2016 yılında tarımsal üretim değeri 269 milyar 671 milyon 586 bin 991 TL'dir. Buna karşın pazarlama değeri ise 182 milyar 576 milyon 581 bin 742 TL'dir. Bu rakama bir sonraki sezon için ayrılan tohumlar, çeşitli nedenlerle ticaretleştirilemeyen ürünler ve kayıt dışı yapılan satışlar dahil edilmemiş olsa da tarımsal pazarlama bakımından büyük bir sorunun mevcudiyetini somutlaştırması adına sunulan bir tutardır. Tarımsal üretim değeri ile tarımsal pazarlama değeri arasındaki uçurum, her yıl pazarlama sorunundan kaynaklı 87 milyar 95 milyon 5 bin 249 TL tarımsal gelir kaybının varlığının göstergesidir. Türkiye İhracatçılar Meclisi (TIM) 2016 yılı sektörel bazda ihracat rakamlarına göre Türkiye'nin 2016 yılı aralık ayı tarım sektörü ihracat rakamı 20 milyar 229 milyon 167 bin Dolar'dır. 2016 dolar kuru baz alındığında Türkiye'nin 2016 yılı tarımsal ihracat tutarı 71 milyar 190 milyon 484 bin 506 TL'dir (TCMB 2018). Bu rakamlar baz alındığında, Türkiye'de üretilen tarımsal ürünlerin pazarlama değerinin sadece \% 38,99'nun ihracatı yapılabildiği sonucu ortaya çıkmaktadır. Bu bilgiler de gösteriyor ki ciddi manada tarımsal ürün ihracat sorunu ülke ekonomisinde mevcudiyetini sürdürmektedir. Tablo 1'de dördüncü kategori olan tarımsal kurum ve kuruluşlardan destek alma durumuna baktığımızda; üreticilerin meslek odalarından ve il müdürlüklerinden destek almadığı beyanları yer almaktadır. 6964 sayılı Ziraat Odaları ve Ziraat Odaları Birliği Kanunu'nun 1. maddesinde “ziraat odaları, bu Kanunda yazılı esaslar uyarınca meslek hizmetleri görmek, çiftçilerin müşterek ihtiyaçlarını karşılamak, meslekî faaliyetlerini kolaylaştırmak, çiftçilik mesleğinin genel menfaatlere uygun olarak gelişmesini sağlamak, meslek mensuplarının birbirleri ve halk ile olan iliş̧kilerinde dürüstlüğü ve güveni hâkim kılmak, meslek disiplin ve ahlâkını kollayıp gözetmek, çiftçilikle işstigal edenlerin meslekî hak ve menfaatlerini korumak amactyla kurulan, tüzel kişiliğe sahip kamu kurumu niteliğinde meslek kuruluşlarıdı" ş̧eklinde ziraat odaların görevleri tanımlanmıştır. Ancak ilgili kurum ve kuruluşların özellikle ziraat odalarının işlevini yerine getirmediği katılımcılar tarafından vurgulanmaktadır. Buna göre üreticiler ziraat odasının ve il müdürlüğ̈nün verdiği hizmeti yeterli görmemektedir. Beşinci kategori olan eğitim başlığı altındaki katılımcı örnek ifadelerini incelediğimizde üreticilerin eğitim taleplerinin olduğu görülecektir. Bilecik İl Gıda Tarım ve Hayvancılık Müdürlügü 2016 yılı verilerine göre 125 üreticiye kiraz yetiştiriciliŭgi, 86 üreticiye zararlılarla mücadele konusunda, 240 üreticiye süne kıymetlendirme sürvey hakkında ve 546 üreticiye ise dört yapraklı yonca hakkında kurum teknik personeli tarafından eğitim verilmiştir (BİGTHM2016: 66-68). Ancak örnek ifadeler gösteriyor ki; üreticiye yönelik adı geçen kurum tarafından verilen mesleki eğitimler üreticiler tarafından yeterli görülmemektedir. Çalışma esnasında üreticilerin, tarımsal kurum ve kuruluşlardan teorik değil arazide 
uygulamalı olarak eğitim almak istedikleri müşahede edilmiştir. Bir sonraki kategori olan genç nüfus durumu incelendiğinde, genç nüfusun azaldığı ve özendirilmesi gerektiği ifade edilmiştir. Genç nüfus çeşitli gerekçeler ile köyden kentlere göç etmektedir. Bunun sonucu olarak aktif üretimdeki tarımsal nüfus azalmaktadır. 2002 yılında 69.3 milyon nüfusun 23.7 milyonu $(\% 34,2)$ tarımla uğraşırken 2011 yılında 74.7 milyon toplam nüfusun sadece \%23,2 tarımla uğraşmakta idi. Türkiye'nin genel nüfusunun artmasına rağmen tarımsal nüfusun \% 34,2'den \% 23,2'ye gerilemesi köyden kente göçün bir göstergesidir. Ayrıca toplam istihdamın artmasına rağmen tarımsal istihdam \% 34,9'dan (2002 yılında) \% 25,5'e (2011 yılında) gerilemiştir (TOBB 2013:1). Türkiye'de kırsal nüfus gün geçtikçe azalmaktadır. 1927 yılında 13,6 milyon olan toplam nüfusun \%75,8'i kırsal nüfusu teşkil etmekteyken, kırılma noktası olan 1950 yılına gelindiğinde 16,1 milyon olan toplam nüfusun \% 75'i kırsal nüfus idi. 1950 yılından itibaren sürekli düşüş eğilimi gösteren kırsal nüfus 1980 yılında 44,7 milyon toplam nüfusun \% 56,1'i seviyesine gerilemiştir. 2012 ylllına gelindiğinde Türkiye nüfusu 75,6 milyon olmasına rağmen kırsal nüfus 17,1 milyon (\% 22,7) seviyesinde kalmıştır. Kentsel nüfus hızla artarken kırsal nüfus kent nüfusuna kıyasla zaman geçtikçe erimiştir (Yılmaz 2015:165)Bu bilgiler Tablo1'deki genç nüfus kategorisindeki katılımcıların tarımsal genç nüfusun azaldığı yönündeki ifadelerini doğrulamaktadır. Genç nüfus ile ilişkili bir sonraki kategori olan işçilik ücretleri hususunda da bir sorunun varlığı görülmektedir ( Tablo1).Tarımsal üretim işgücüne dayanan bir faaliyettir. Dolayısıyla işçilik ücretleri üretim maliyetlerinde önemli bir gider kalemidir. İşçilik ücretlerindeki artış otomatik olarak ürün fiyatlarına yansımaktadır. Bu durum hem üreticiyi hem de tüketiciyi olumsuz etkilemektedir. İşçilik ücretleri kategorisinde belirtilen işçilik maliyetleri çok yüksek ifadesini istatistiki veriler de doğrulamaktadır (Tablo 1). TÜíK'in 2016 yılı tarımsal işletme işgücü ücret yapısı verilerine göre 2015 yılında mevsimlik kadın erkek işçi günlük ücreti ortalaması $52 \mathrm{TL}$ iken 2016 yılında \% 13,4 artışla 59 TL'ye yükselmiştir. 2015 yılında sürekli kadın erkek işçi aylık ücret ortalamas1 1.532 TL iken 2016 yılında \% 9,5 artarak 1.677 TL’ye yükselmiştir. Bu rakamlar işçi ücretlerinin artış eğiliminde seyrettiğini ortaya koymaktadır. Tablo '1 de bir başka kategori olan miras yasasına baktığımızda katılımcıların miras yasası nedeniyle arazilerin bölünmesini istemediği görülmektedir. Türkiye'de miras bölünmesi nedeniyle tarım arazileri küçük parçalara ayrılmakta ve verimli araziler üretim dışı kalmaktadır. Bunun önüne geçilmesi amacıyla Türkiye'de ilk olarak 1961 yılında köy bazlı basit arazi toplulaştırılması başlatılmıştır. 2014 yılında bu konuya daha fazla önem verilmiş ve 6537 sayılı Toprak Koruma Ve Arazi Kullanımı Kanununda Değişiklik Yapılması Hakkında Kanun yürürlüğe girmiştir. 2012 yılına kadar 2.953 .602 ha alan toplulaştırılmıştır. Toplam 14 milyon ha alan toplulaştırılması hedeflenmektedir (Küsek 2014:5). Bu bilgiler gösteriyor ki arazi toplulaştırılması hususunda çalışmalar yapılmakta ancak tamamlanması için zaman gerekmektedir. Bir başka husus olan ve gün geçtikçe önemi artan üretim miktarı planlaması konusunu irdeleyelim. Tarımsal üretimin kendine has özelliği nedeniyle üretim ile arz eşit değildir. Yani üretilen her ürün piyasaya sunulmaz. Üretilen ürünlerden bir kısmı tohumluk ve tüketim için ayrılırken kalan kısım arz edilir (Dinler 1993:200). Diğer ürünlerde olduğu gibi tarım ürünlerinde de talep fonksiyonu geçerlidir. 
Rekoltenin yüksek olduğu yıllarda arz fazlalığı nedeniyle ürün fiyatlarında düşme, rekoltenin düşük olduğu yıllarda ise ürün fiyatlarında artma meydana gelir. Ürün fiyatlarında düşüş olması nedeniyle üreticinin geliri de azalmaktadır (Dinler 1993: 233). Bu sorunun giderilmesi için üretim miktarlarının düzenlenmesi ve planlanması gerekmektedir. Tablo1'de üretim miktarı planı kategorisinde bu durum katılımcılar tarafından dile getirilmiştir. Bu sorunun tarım politikasıyla bağlantısı mevcuttur. Çünkü coğrafi bölgelere göre tarımsal ürün yetiştirme planlaması devlet tarafindan kontrolü yapılmalıdır. Tarım politikası üreticilerin ekonomik seviyelerini yükseltmek, tarımsal üretimi kamu yararına düzenlemek, kırsal nüfusun refah düzeyini artırmak, üreticiyi ve tüketiciyi fiyat dalgalanmalarından korumak için devlet tarafından yürütülür (İnan 2006:108). Tarım politikalarının yürütülmesinde en önemli husus istikralı bir süreçtir. Tarım politikası hükümet politikası olmaktan öte devlet politikası olması gerekmektedir. Katılımcılar Tablo 1'de on birinci sırada yer alan kategorideki örnek ifadede, istikrarlı ve kararlı tarım politikaları izlenmeli, popülist politikalar terk edilmeli vurgusu yapmıştır. Tarım politikası sadece desteklemelerden oluşmamalıdır. Sadece üretim ve üretici temelli değil pazarlama, tüketim ve tüketici de merkeze alınmalı, ihracat öncelenmelidir (TİM 2016: 95). Grafik 1 'de Bilecik'te üretim yapan üreticilerin ulaşım sorunu \% 3,01 gibi düşük bir oransal durum ortaya çıkmıştı. Tablo 1'de de sorunun mevcudiyeti tekrarlamaktadır. Türkiye'de tarım sektöründen Gelir Vergisi, Katma Değer Vergisi ve Emlak Vergisi olmak üzere üç çeşit vergi alınmaktadır (Hayran 2013:70-71). 1319 sayılı Emlak Vergisi Kanunu'nun Geçici Muaflıklar başlıklı 15. maddesi tarım arazilerine geçici muafiyetler tanımıştır. Buna göre tarım yapılamayan sahaların, sslah tedbirleriyle yeniden tarıma elverişli hale getirilmesinde 10 yıl, meyvelik, bağ ve bahçe meydana getirilmesinde asgari 2 yıl, azami 15 yıl emlak vergisinden muaf tutulmaktadır. Aynı kanunun 4. maddesi c bendi gereğince ise köylere ve köy birliklerine ait tarım işletme binaları, soğuk hava depoları, içmeler ve kaplıcalar ile bunlar tarafından köylünün umumi ve müşterek ihtiyaçlarını karşılamak maksadıyla işletilen hamam, çamaşırhane, değirmenler ve köy odaları daimi olarak emlak vergisinden muaf tutulmaktadır. Tarımsal üretim de ayrıca uygulanan bir vergi usulü yoktur. Ancak üretim için gerekli makine/ ekipman, gübre, ilaç, akaryakıt, tohum gibi girdilerin satın alınması esnasında ödenen Katma Değer Vergisi (KDV) ve elde edilen ürünlerin satış1 sırasında ödenen KDV tutarları üreticileri zorlamaktadır. Buna elde edilen yıllık miktardan ödenen Gelir Vergisi de eklendiğinde durum daha da zorlaşmaktadır. Bu nedenle katılımcılar vergilerin yüksek olduğunu belirtmişlerdir (Tablo 1). KDV sadece tarım sektöründe değil tüm sektörlerde uygulanan bir vergi türüdür. Bu nedenle mevcut sorun tüm sektörleri kapsamaktadır.

Tablo 1 özelinde son olarak şunlar söylenebilir; tablodaki mevcut durum ile tarım sektörüne ait sayısal verilerin bir birini teyit etmesi üreticilerin sorunlarının gerçekçi olduğunun kanıtıdır. Ortaya konulan bu sorunların çözümü karar vericilerin yetkisi dahilindedir. Bu bağlamda tarım politikasının gözden geçirilmesi gerekliliği ve yeni düzenlemelere ihtiyaç duyduğu gerçeği ortaya çıkmaktadır. 
Katılımcılara yöneltilen "tarımsal üretimin artması için sizce öncelikle neler yapılmalıdır" soruna 116 katılımcıdan alınan Tablo 2'de yer alan yanıtlara sosyal bilimler için nitel veri analizi yapılarak Resim 1'deki kelime bulutu oluşturulmuştur.

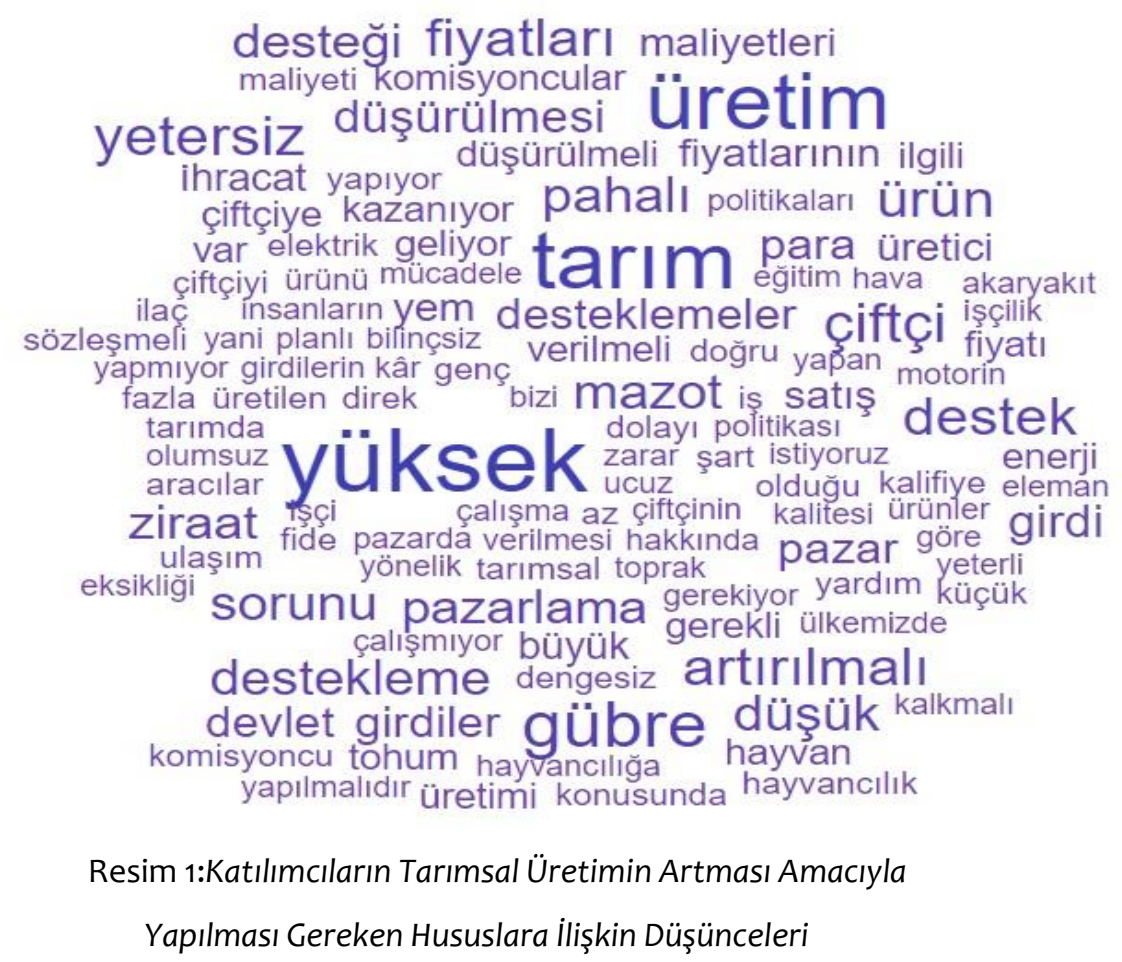

Katılımcıların verdiği yanıtlarda tekrar sayısına göre görselleştirilen Resim 1'deki kelime bulutunda, üretim, yüksek ve gübre kelimeleri öne çıkmaktadır. Bunları pazarlama, destekleme, girdi, düşük, yetersiz, pazar mazot kelimeleri takip etmiştir. Buradan yola çıkarak katılımcıların büyük çoğunluğu tarımsal girdi bedellerinin fazlalığından şikayet ettiği söylenebilir. Resim 1'de kelime bulutunda katılımcılar tarafından söz konusu tarımsal girdilerden, en çok gübre ve mazot kelimeleri ifade edilmiştir. Bunları tohum, elektrik ve ilaç takip etmiştir. Daha önce bazı girdi kalemlerindeki yıllara göre astronomik fiyat artış verileri sunulmuştu.TÜíK'in 2016 yılı net elektrik tüketiminin sektörlere göre dağılımı verilerine göre Türkiye'de üretilen $231.204 \mathrm{GWh}$ elektriğin \% 6,4'ü tarım ve sulamada kullanılmaktadır. TÜIK'in 2012 yılı elektrik ve doğalgaz fiyatları verilerine göre sanayide en düşük kullanım aralığı olan 20MWh altındaki $1 \mathrm{KWh}$ elektrik bedeli 26,8 kuruş, 2014 yılında 27,7 kuruş, 2016 yılında ise 30,3 kuruş olarak fiyatlandırıldı. Buna göre beş yıl içerisinde elektrik birim fiyatları \% 13,06 artmıştır. Tarımsal üretim için gerekli malzeme ve ekipmanların ve aynı zamanda elektrik ve akaryakıt gibi enerji girdilerinin yüksek olması tarım işletmelerinin rekabet gücünü zayıflatmaktadır. Tarım işletmelerinin yurt içi ve özellikle yurt dışı pazarlarda etkin rekabet edebilir hale gelmesi için üretim maliyetlerinin düşürülmesi bir zorunluluk olarak karşımızda durmaktadır. Resim 1'deki kelime bulutunda, Bilecik ilinde faaliyet gösteren tarımsal ürün üreten 
üreticilerle yapılan anket sonuçlarına göre üretim girdilerinden sonra pazarlama sorunun varlı̆̆1 ortaya çıkmaktadır. Günümüzde en az ürün veya hizmet üretmek kadar pazarlamak da çok önemlidir. Pazarlama sadece iç piyasaya arz olarak algılanmamalıdır. Yurtdışı pazarlama ile yüksek gelir elde edilebilmesi ve GSMH'ya katkı sağlayabilmesi açısından son derece önemlidir. Türkiye İhracatçılar Meclisi'ne göre tarımsal pazarlamanın önündeki engeller; tanıtım sorunu, ticarileşme ve markalaşma eksikliği, satış sonrası hizmet ve destek eksikliği, pazar ve müşteri ihtiyaçlarının yeterince analiz edilmemesi, web ve sosyal medya kullanımında eksiklik, devlet destekli fuarların özenle seçilmemesi, düşük fuar teşvik oranı, fuar teşvik prosedürlerinin çokluğu, Türkiye'de düzenlenen uluslararası fuarlara teşvik olmaması, yurt dışında ticari teşkilatlanma eksikliğidir (TíM 2016:143). Araştırmaya katılan tarım işletmelerinin, tarımsal üretimin artması yönünde belirttikleri bir başka husus tarımsal desteklerdir. Ülkemizde tarım işletmelerine motorin, tohum, fide, fidan, gübre, makine ekipman, arge, yem, analiz, biyolojik mücadele, organik tarım gibi çok çeşitli destekler, kamu kurum ve kuruluşları, kooperatifler tarafından sağlanmaktadır. Söz konusu desteklerin miktarları ve çeşitlilikleri arttıkça üreticilerin rekabet gücü artacak ve işletmelere uzun süre varlıklarını sürdürme şansı verilmiş olacaktır. Desteklerin bir başka önemi ise tarımsal üretimin devamlılığını sağlamaktır. Çünkü Ülkemiz için tarım önemli üretim sektörleri arasındadır. Tarımsal üretim sektörünün körelmemesi, bu sektörün aksine büyüyerek iç piyasadan gelecek tüm talepleri karşılayıp dış piyasalardan gelecek taleplere de cevap verebilir hale gelmesi ülke ekonomisi için elzemdir. Bilecik'te 2016 yılında 24 milyon 402 bin 168 TL 48 kuruş tarımsal destek ödemesi yapılmıştır. Bu tutarın \% 40’ı kırsal kalkınma destekleri içerisinde hayvancılık desteklemeleri, \% 38'i bitkisel üretim destekleme, \% 16'sı kırsal kalkınma desteklemeleri, \% 6'sı hayvancılık desteklemeleri, \% 0,27'si tarımsal yayım ve danışmanlık desteklemelerini oluşturmaktadır. 2002 yılında yaklaşık 8 milyon TL destekleme ödemesi yapılmışken 2016 yılında bu rakam 3 kat artmıştır (BİGTHM 2016:22). Ancak araştırma sonucuna göre Bilecik ilinde faaliyet gösteren üreticiler, tarımsal desteklemeleri miktar ve çeşitlilik bazında yetersiz görmektedir. Söz konusu işletmelerin, araştırma sonucunda ortaya çıkan diğer bir problemi, ürün fiyatlarının düşük olmasıdır. Türkiye'de tarım sektöründe küçük ölçekli üreticilerin ağırlıklı olması nedeniyle üretim ve pazarlama zincirinin uzunluğu, nihai ürün piyasalarında fiyat dalgalanmalarına neden olabilmektedir. Bunların dışında özellikle yurt içi piyasasında spekülatif kaynaklı fiyat dalgalanmaları oluşmaktadır. Devlet bu tür fiyat dalgalanmalarına doğrudan ya da direk olarak müdahale etmektedir. Taban fiyat uygulaması bu argümanlardan bir tanesidir. İç piyasada fiyat dalgalanmasının en önemli kaynağı arz talep dengesizliğidir. Bunun önüne geçilebilmesi için uzun vadede istikrarlı ve rekabet gücü yüksek bir tarım sistemine, bunu sürekli kılacak tutarlı tarım politikalarına ihtiyaç duyulmaktadır. Kısa vadede ise TMO Tarım Satış Kooperatifleri Birlikleri tarafından yıl içerisinde yürütülecek stok yönetimi spekülatif hareketleri önleyebilecek ve ürün rekolte miktarları ile toplam yurtiçi talep gözetilerek coğrafi bazda tarımsal ürün ve miktar belirleme stratejisi uygulanmalıdır. Diğer taraftan dış ticaretin artmasıyla tarımsal ürün fiyat dalgalanmalarının önüne geçilebileceği öngörülmektedir (DPT 2008:62). Resim 1'deki kelime bulutunda yukarıda ifade edilen 
sorunlardan sonra semt pazarlarında üreticilere satış yeri tahsis edilmemesi, kalifiye eleman yetersizliği, ulaşım, olumsuz hava koşulları, hayvansal üretime daha fazla önem verilmesi gibi sorunların dile getirildiği görülmektedir. Çalışma esnasında üreticilerin umutlu oldukları, var olan tüm sorunlara rağmen Ülkemizin tarımsal üretim bakımından gerekli tüm doğal hava koşullarını barındırdığının bilincinde oldukları gözlemlenmiştir. Sahip olunan bu potansiyel enerji, kinetik enerjiye dönüştürülmesi durumunda, Ülkemiz ekonomisinin ivme kazanacağı düşünülmektedir.

\section{Sonuç Ve Tartışma}

Bilecik ilinde tarımsal üretim yapan üreticilerin tarımsal üretimin önündeki engeller ve yapılması gerekenler hususunda görüşlerini birincil elden yansıtmak amacıyla bu çalışma gerçekleştirilmiştir. İl merkezinde ve ilçelerde üretim yapan 135 üretici çalışmaya katılmıştır. Katılımcılara yöneltilen açı uçlu soruya alınan yanıtlara sosyal bilimlerde içerik analizi uygulanmıştır. Buna göre Grafik 1, Tablo 1 ve Resim 1 oluşturulmuştur. Grafik 1'de (hiyerarşi grafiği) Bilecik'teki tarımsal üretimin önündeki engeller sorgulanmıştır. Katılımcılara tarımsal üretimin önündeki engeller sorulmuş, 14 madde cevap olarak sunulmuş ve katılımcıların birden fazla seçenek belirlemesine müsaade edilmiştir. Her bir seçeneğin belirtilme sayısına göre oransal sıralama yapılmıştır. Buna göre tarımsal üretimin önündeki en büyük engel olarak; ilk sırada motorin fiyatlarının yüksek olması (\% 11,60), bunu gübre fiyatlarının yüksek olması $(\% 10,54)$, üçüncü sırada ise ilaç fiyatlarının yüksek olması (\% 10,09) takip etmektedir. Bu üç madde tarımsal üretimin ana girdi kalemleridir. Bunları, tohum fiyatlarının yüksek olması (\% 6,93), olumsuz hava koşulları $(\% 6,93)$, elektrik fiyatının yüksek olması (\% 5,87), işçi ücretlerinin yüksek olması (\% 6,17), verginin yüksek olması seçeneğinin (\% 3,92), nakliye ücretinin yüksek olması $(\%$ 4,07) takip etmiştir. 2002 yılından 2017 y1lına kadar geçen sürede akaryakıt fiyatında \% 442,55 gibi astronomik artış meydana gelmesi ve çiftçinin yaygın olarak kullandığı Diamonyum Fosfat (DAP) gübre fiyatları 2003 yılında tonu 388 TL iken 2017 yılında \% 285,02 artışla 1.493,90 TL'ye yükselmesi karş11ık, 2014 yılı ocak ayında domatesin kilogram satış fiyatı 1,53 TL iken 2015 yılı eylül ayında bu rakam \%35,29 düşüşle 0,99 TL'ye gerilemesi Tablo 1'de verilen sonuçları teyit etmektedir. "Tarımsal üretimin artması için sizce öncelikle neler yapılmalıdır" sorusuna katılımciların verdikleri cevaplar Tablo 1'de numuneleştirilmiştir. 135 katılımcıdan 19'u (\%14,07) soruya cevap vermemeyi tercih etmiştir. Elde edilen veriler çerçevesinde 12 kategori belirlenmiş bunların dışında olanlar ise diğer kategorisi içerisine dahil edilmiştir. Türkiye'nin 2015 yılı vergi ve süspansiyondan arındırılmış GSMH'sı 2 trilyon 60 milyar 726 milyon 789 bin TL'dir. Aynı yıl altı ana başlıkta tarımsal desteklere ayrılan pay ise 9 milyar 971 milyon $(\% 0,48)$ TL'dir. 2017 yılı bütçe toplamı 1.243,4 milyar TL'dir. GSMH 2017 yılında 3 trilyon 104 milyar 907 milyon TL olarak gerçekleşmiştir. Bütçeden, tarımsal desteklere ayrılan pay ( 12,8 milyar TL), GSMH'nın yüzde birinden az olarak sadece \% 0,41 seviyesinde kalmıştır. Bu veriler ışığında tarımsal üretim yapan üreticilerin daha fazla desteklenmesi gerektiği söylenebilir. 2014 y1lında 5,7 milyar dolar tarımsal girdi ithal ederken buna karşın 3 milyar dolar ihracat gerçekleşmiştir. Ülkemizde ithalata dayalı bir tarımsal girdi söz konusudur. Bunun en kısa 
zamanda tersine çevrilmesi elzemdir. TÜİK'in bitkisel ve hayvansal üretim değerleri verilerine göre Türkiye'de 2016 yılında tarımsal üretim değeri 269 milyar 671 milyon 586 bin 991 TL'dir. Buna karşın pazarlama değeri ise 182 milyar 576 milyon 581 bin 742 TL'dir. Bu rakama bir sonraki sezon için ayrılan tohumlar, çeşitli nedenlerle ticaretleştirilemeyen ürünler ve kayıt dışı yapılan satışlar dahil edilmemiş olsa da tarımsal pazarlama bakımından büyük bir sorunun mevcudiyetini somutlaştırması adına sunulan bir tutardır. Tarımsal üretim değeri ile tarımsal pazarlama değeri arasındaki uçurum, her y1l pazarlama sorunundan kaynaklı 87 milyar 95 milyon 5 bin 249 TL tarımsal gelir kaybının varlığının göstergesidir. Türkiye'nin 2016 yılı tarımsal ihracat tutarı 20 milyar 229 milyon 167 bin Dolar'dır. 2016 dolar kuru baz alındığında Türkiye'nin 2016 yılı tarımsal ihracat tutarı 71 milyar 190 milyon 484 bin 506 TL'dir. Türkiye'de üretilen tarımsal ürünlerin pazarlama değerinin sadece \% 38,99 'nun ihracatı yapılabildiği sonucu ortaya çıkmaktadır. Katılımcıların ifade ettiği pazarlama ve ihracat sorununun varlığını sayısal veriler de doğrulamaktadır. Bir başka husus tarımsal kurum ve kuruluşlardan destek alma kategorisinde üreticilerin meslek odalarından ve il müdürlüklerinden destek almadığı beyanları yer almaktadır. Özellikle ziraat odalarının işlevini yerine getirmediği vurgulanmaktadır. 2016 yılı verilerine göre 125 üreticiye kiraz yetiştiriciliği, 86 üreticiye zararlılarla mücadele konusunda, 240 üreticiye süne kıymetlendirme sürvey hakkında ve 546 üreticiye ise dört yapraklı yonca hakkında teknik personel tarafından eğitim verilmiştir. Ancak üreticiler ziraat odasının ve il müdürlüğünün verdiği hizmeti yeterli görmemektedir. Tarımsal üretimdeki genç nüfusun azalması bahsine gelindiğinde vahim bir tablo ile karşılaşılmaktadır. 2002 yılında 69.3 milyon nüfusun 23.7 milyonu $(\% 34,2)$ tarımla uğraşırken 2011 yılında 74.7 milyon toplam nüfusun sadece $\% 23,2$ tarımla uğraşmakta idi. Türkiye'nin genel nüfusunun artmasına rağmen tarımsal nüfusun \% 34,2'den \% 23,2'ye gerilemesi köyden kente göçün bir göstergesidir. Ayrıca toplam istihdamın artmasına rağmen tarımsal istihdam \% 34,9'dan (2002 yılında) \% 25,5'e (2011 yılında) gerilemiştir. Anket formunda yer alan açık uçlu soruya muhatapların verdiği cevaplar analiz edilmiş, tekrar sayılarına göre kelime bulutu oluşturulmuştur. Oluşturulan kelime bulutunda, üretim, yüksek ve gübre kelimelerinin öne çıkması dikkat çekmiştir. Katılımcıların büyük çoğunluğu tarımsal girdi bedellerinin fazlalığından şikayet etmiştir. Kelime bulutunda katılımcılar tarafından söz konusu tarımsal girdilerden, en çok gübre ve mazot kelimeleri ifade edilmiştir. Bunları tohum, elektrik ve ilaç takip etmiştir. Daha sonra ise pazarlama sorunun varlığı ifade edilmiştir. Araştırmaya katılan üreticilerin, tarımsal üretimin artması yönünde belirttikleri bir başka husus tarımsal desteklerdir. Ülkemizde tarım işletmelerine motorin, tohum, fide, fidan, gübre, makine ekipman, arge, yem, analiz, biyolojik mücadele, organik tarım gibi çok çeşitli destekler, kamu kurum ve kuruluşları, kooperatifler tarafından sağlanmaktadır. Tarım sektörü, sanayi sektörüne hammadde sağlaması ve istihdamı direk ya da en direk etkilemesi nedeniyle etki alanı oldukça geniştir. Bu nedenlerden dolayı tarımsal üretimden vazgeçilmesi mümkün değildir. En önemlisi ise tarım sektörünün insanların gıda ihtiyaçlarını karşılaması hasebiyle hayati öneme haizdir. Araştırma sonucuna göre Bilecik ilinde faaliyet gösteren tarımsal ürün üreten üreticilerin, tarımsal desteklemeleri miktar ve çeşitlilik bazında yetersiz görmektedir. Söz konusu 
üreticilerin, araştırma sonucunda ortaya çıkan diğer bir problemi, ürün fiyatlarının düşük olmasıdır. Ürettikleri ürünlerin, değerinden düşük fiyat karşıllğı bulması, üreticilerin şevkini kırmaktadır. Bunun en başta gelen nedeni arz talep dengesizliğidir. Olumsuz hava koşulları ve spekülatif stoklamalarda buna ilave edilebilir. Tarladaki ürün birim fiyatı ile pazar veya marketteki ürün birim fiyatı arasında büyük farkların ortaya çıkması, bu noktada bir sorunun olduğunu göstermektedir. Bunun önüne geçilebilmesi için bölgesel ürün belirlenmeli, her sezon bu liste güncellenmeli ve bu üretim dağılımı planına sadık kalınarak üretim gerçekleştirilmelidir. Bu sayede ülke kaynakları israf edilmemiş olacak, üreticiler emeklerinin karşılığını alırken tüketiciler de uygun fiyata ürün temin etmiş olacaklardır. Kelime bulutunda yukarıda ifade edilen sorunlardan sonra semt pazarlarında üreticilere satış yeri tahsis edilmemesi, kalifiye eleman yetersizliği, ulaşım, olumsuz hava koşulları, hayvansal üretime daha az önem verilmesi gibi sorunlar dile getirilmiştir. Bu sorunların kısa vadede çözümü mümkün görülmemekle birlikte istikrarlı ve gerçekçi tarım politikaları ile uzun vadede çözüme kavuşacağı ön görülmektedir. Araştırmanın kısıtları olarak şunlar ifade edilebilir; bazı üreticilerin yerleşim yerlerinden çok uzak olması, araziye ulaşımın hayvan ya da traktörle sağlanması nedeniyle ulaşım yapılamamıştır. Belli bir sabit üretim yeri olmayan arı yetiştiricilerden çok azına ulaşılabilinmiştir. Bazı tavuk çiftliklerine virüs bulaşma riski nedeniyle giriş yapılamamıştır. Kırsalda küçükbaş ve büyükbaş hayvan yetiştiricilerinden çok azına ulaşılabilmiştir. Hayvanları sürekli farklı yerlerde otlattıkları için az sayıda hayvan yetiştiricisine ulaşılabilmiştir. Çalışmaya katılanların eğitim düzeyleri çok farklı olduğu için aradaki makas açısının fazlalığı soruların tüm katılımcılar tarafından aynı seviyede anlaşılmasını engellemiştir. Araştırmada kadın katılımcı sayısı tatminkar değildir. Bir çok alabalık tesisinde sadece işçilerin olması veya hiç kimsenin olmaması nedeniyle buralarda çalışma yapmak mümkün olmamıştır. Çalışma öncesinde her ilçeden en az 30 üretici ile merkez ilçe dahil 8 ilçede çalışma planlanmıştı. Faaliyet alanı olarak homojen dağılımı sağlamak için toplam üretici sayısına ve faaliyet alanı yoğunluğuna göre belirlenecek oranlar sonucunda bulunacak sayılarda geniş bir yelpazede tarım işletmeleri ile çalışma yapılması hedeflenmişti. Ancak bu hedef kısmen gerçekleştirilebilmiştir. Son olarak; Bilecik'teki tarımsal üretim sorunları ülke genelindeki sorunlarla aynıdır. $\mathrm{Bu}$ sorunlar yetkililerin çözüm üretebileceği nitelikte sorunlardır. Kısa vadede çözüme kavuşturulması mümkün görülmese bile uzun vadede istikrarlı çalışmalar ile sorunların kahir ekseriyetinin çözüme kavuşacağı ön görülmektedir. Bilecik fiziki şartlar bakımından tarımsal üretime oldukça müsaittir. Uygun iklim koşulları, yeterli su kaynakları, çeşitli yenilenebilir enerji kaynakları, liman ve şehirlere yakınlık, verimli arazilerin mevcudiyeti gibi tarımsal üretim potansiyellerinin sahip olduğu enerjinin, kinetik enerjiye dönüştürülmesiyle, il ve ülke ekonomisinin ivme kazanacağı düşünülmektedir. 


\section{Kaynaklar}

BİGTHM (Bilecik İl Gıda Tarım ve Hayvancıllk Müdürlüğü (2016), 2016 Yll ll Brifingi. [Erişim Tarihi: 02/06/2018,

https://bilecik.tarim.gov.tr/Belgeler/2016\%20YILI\%20\%C4\%B0L\%20BR\%C4\%B0F\%C4\%B0NG\%C4\%B0.pd $\underline{\text { f. }}$

Bilgin, Nuri (2006), Sosyal Bilimlerde İçerik Analizi, Birinci Baskı, Siyasal Kitabevi Yayınları: Ankara.

BÜGM (Bitkisel Üretim Genel Müdürlüğü (2017), Bitkisel Üretim Verileri. [Erişim Tarihi: 18/04/2018, https://www.tarim.gov.tr/sgb/Belgeler/SagMenuVeriler/BUGEM.pdf .

BÜMKO (Bütçe ve Mali Kontrol Genel Müdürlüğü (2019), 2017 Bütçesine Genel Bakış- Tarım. [Erişim Tarihi: 20/01/2019, http://www.bumko.gov.tr/TR,8125/tarim.html] .

Dinler, Zeynel (1993), Tarım Ekonomisi, 3.Bask1, Ekin Kitabevi Yayınları: Bursa.

Doğan Burtan, Bahar (2014) “Tarımsal Destekleme Politikaları”, Meriç Subaşı Ertekin (Ed.); Tarım Ekonomisi ve Tarımsal Politikalar, 3.Bask1, Anadolu Üniversitesi Web Ofset, Eskişehir, ss.56-76.

DPT (Devlet Planlama Teşkilatı) (2008),Tarım ve Gıda Ürünleri Fiyatlarında Yaşanan Sorunlar ve Öneriler, DPT Yayılları: Ankara, No: 2767.

Hayran, Seyit (2013), “Türkiye'de Tarım Kesiminin Vergilendirilmesi”, Iğdır Üniversitesi Fen Bilimleri Enstitüsü Dergisi, 3(1), ss. 69-72.

İnan, İ.Hakkı (2006), Tarım Ekonomisi ve Isşletmeciliği, Altıncı Baskı, Namık Kemal Üniversitesi Yayınları: Tekirdağ.

İSKGM (İktisadi Sektörler ve Koordinasyon Genel Müdürlüğü (2017), Tarım ve Gıda. [Erişim Tarihi: 08/06/2018, http://tarim.kalkinma.gov.tr/tarim/] .

Karacan, Rıdvan (2014) “Tarımsal Üretim ve Tarımsal Üretimin Türleri”, Meriç Subaşı Ertekin (Ed.); Tarım Ekonomisi ve Tarımsal Politikalar, 3.Baskı, Anadolu Üniversitesi Web Ofset, Eskişehir, ss.2-16.

Küsek, Gürsel (2014), “Türkiye'de Arazi Toplulaştırmasının Yasal Durumu ve Tarihsel Gelişimi”, Çukurova Üniversitesi Ziraat Fakültesi Dergisi, 29(1), ss. 1-6.

Newbold, P. (2009), Isşletme ve İktisat İçin İstatistik(Çev. Ümit Şenesen), Yedinci Baskı, İstanbul:Literatür Yayınları, (1995).

OPET (2017), (Bilecik İli Bozüyük İlçesi 08/12/2017-22/12/2017) Geçmiş Tarihli Akaryakıt Fiyatları. [Erişim Tarihi: 02/05/2018, https://www.opet.com.tr/gecmis-tarihli-akaryakit-fiyatlari\#bilecik] .

T.C. Resmi Gazete, 1319 sayılı Emlak Vergisi Kanunu, 11 Ağustos 1970, Sayı 13576, Başbakanlık Basımevi, Ankara.

T.C. Resmi Gazete, 5488 Sayılı Tarım Kanunu, 18 Nisan 2006, Sayı 5488, BaşbakanlıkBasımevi, Ankara.

T.C. Resmi Gazete, 6964 sayılı Ziraat Odaları ve Ziraat Odaları Birliği Kanunu, 03 Haziran 2004, Say1 5184, BaşbakanlıkBasımevi, Ankara.

TCMB (Türkiye Cumhuriyeti Merkez Bankası (2018), Döviz Kurları. [Erişim Tarihi: 01/06/2018, http://www.tcmb.gov.tr/kurlar/201612/30122016.xml] .

TİM(Türkiye İhracatçılar Meclisi) (2016), 31.12.2016 Tarihi İtibariyle Sektörel Bazda Aylık İhracat Kayıt Rakamlarl. [Erişim Tarihi: 09/05/2018, http://www.tim.org.tr/files/downloads/rakamlar/2016/12/sektorel_bazda_ihracat_rakamlari_aralik_2016.xlsx ].

TİM(Türkiye İhracatçılar Meclisi) (2016), Tarım Raporu 2016, ), [Erişim Tarihi: 29/05/2018, http://www.tim.org.tr/files/downloads/Raporlar/Tarim_Raporu_2017.pdf] .

TOBB (Türkiye Odalar ve Borsalar Birliği) (2013), Türkiye Tarım Sektörü Raporu 2013, TOBB Yayınları: Ankara, No:2014/230.

TUiK (2016), Tarımsal İşletme İşgücü Ücret Yapısı, 2016, 9 Mart 2017 (Rapor No:24565), [Erişim Tarihi: 28/05/2018, http://www.tuik.gov.tr/PreHaberBultenleri.do?id=24565] .

TUIK (2016),Araştırma-Geliştirme Faaliyetleri Araştırmasl, 2015 (Rapor No:21782),[Erişim Tarihi: 27/11/2017, http://www.tuik.gov.tr/PreHaberBultenleri.do?id=21782] . 
TUiK (2018), Dönemsel Gayrisafi Yurt İçi Hasıla, IV.Çeyrek: Ekim-Aralık 2017, Mart 2018 (Rapor No:27825), [Erişim Tarihi: 20/01/2019, http://www.tuik.gov.tr/PreHaberBultenleri.do?id=27825] .

TUIK (2018), Gayrisafi Yurtiçi Hasıla, İktisadi Faaliyet Kollarına (A21) Göre Zincirlenmiş Hacim, Endeks Ve Değişim Oranları. [Erişim Tarihi: 10/05/2018, www.tuik.gov.tr/PreIstatistikTablo.do?istab_id=2515] .

TUIK (2018), İstihdam Edilenlerin Yıllara Göre İktisadi Faaliyet Kolları Ve Dağılımı. [Erişim Tarihi: 07/05/2018, www.tuik.gov.tr/PreIstatistikTablo.do?istab_id=2263] .

TUiK (2018), Tarım Ürünleri Üretici Fiyat Endeksi, Nisan 2018 (Rapor No:27832), [Erişim Tarihi: 27/05/2018, http://www.tuik.gov.tr/PreHaberBultenleri.do?id=27832] .

TUіK(2016), Net Elektrik Tüketiminin Sektörlere Göre Dă̆llımı. [Erişim Tarihi: 08/05/2018, www.tuik.gov.tr/PreIstatistikTablo.do?istab id=1579] .

TUiK(2017), Bitkisel Ve Hayvansal Üretim Değerleri. [Erişim Tarihi: 12/05/2018, www.tuik.gov.tr/PreIstatistikTablo.do?istab_id=1311] .

TÜIK ( Temmuz 2004), 2001 Genel Tarım Sayımı. TÜiK Matbaası. Ankara.

TZOB(Türkiye Ziraat Odaları Birliği) (2013), Yıllara Göre Mazot Fiyatları. [Erişim Tarihi: 01/05/2018, http://ziraatodasi.gen.tr/profile/?u=84;area=showposts;sa=topics;start=570] .

Yılmaz, Murat (2015), “Türkiye'de Kırsal Nüfusun Değişimi ve İllere Göre Dağılımı(1980-2012)”, Doğu Coğrafya Dergisi, 33(1), ss. 161-188. 